\title{
Inference and Implication from a Lightning Observation
}

\author{
Miah M Adel \\ Department of Chemistry \& Physics, University of Arkansas at Pine Bluff 1200 \\ North University Drive, Pine Bluff, AR 71601, USA \\ adelm@uapb.edu
}

Abstract: Lightning is a dangerous natural phenomenon which cannot be replicated artificially because of the enormous strength of the event. Its observation reveals information on why a particular object and not others on the ground will be hit. It is observed that lightning hits tall towering trees, animals, metal objects, animals carrying metal objects, electric wirings, plumbing lines, etc. Date trees, coconut trees, and palm trees are all alike. The lightning incident described here finds a small date tree is more favorable than other much taller trees of the same family and metal-capped tall temples when all these potential subjects are present in a congested place. This favoritism is likely due to the sap-abundance in date trees. Also, it shows that side flashes in the form of whitish patches of light from around the lightning-hit spot can travel over long distances across water bodies. The patches of white flash give burning sensation on the skin. It reinforces the conclusion that side flashes from lightning can jump/fly from the lightning spot to try to pass through human or other animal subjects to the ground. So, it is not safe to stand near or under a tree or near a water body during lightning. Overpopulated agricultural tropical countries like Bangladesh where every inch of land is used for production and where lightning takes a heavy toll for upstream water piracy-related climate change and shortage of trees should grow abundantly date trees which absorb moisture from deep underground and do not obstruct agricultural production around it.

Keywords: Lightning, cumulonimbus cloud, electrons, expansion, condense, landscape, date tree, tree roots, dighi, temple, water body, heat storage, groundwater irrigation, top soil, and wild-grown trees

\section{INTRODUCTION}

Lightning safety is a global issue. Lightning causes deaths and injuries to humans and livestock and damages property. General public should have the knowledge of protection from a lightning-strike so that life and property losses are kept to a minimum. The earth receives about 100 lightning every second and every year lightning kills more people than tornadoes and hurricanes and most of these deaths take place in open fields near or under trees or around water. Holle (NLSI, 2012) reported about 24,000 lightning-struck deaths and about 240,000 lightning-struck injuries globally every year (Al-Abdulaziz et al., 2006; Coleman, 1993; Demirkol et al., 1999; Djalel et al., 2007; Halasa et al., 2007; Khan et al., 2002; Koopman and Wilkerson, 1971; Meredith et al., 2010a; 2010b; Odeh, 2009; Petersen et al., 2008; Rambo et al., 1999; Saum and Koopman, 1972; Stolzenburg and Marshall, 2008). National Geographic News reports (Dell'Amore, 2010) of more lightning victims than snow storms, hurricanes and tornadoes. Only floods can supersede this figure for lightning. Lightning-related injuries range from severe burns and permanent brain damage to memory loss and personality change.

Lightning is a neutralization of electric charge in which positive and negative charges from separate locations combine. This neutralization can happen between two parts of the same cloud, two different clouds, and clouds and the ground. Lighting is a momentary event whose details are not commonly observed. It occurs in cumulonimbus clouds. The condition for lightning is the creation of positive and negative charges separated in two parts of a cumulonimbus cloud. It is believed that the charges develop through friction. The layer of positive charges resides above the layer of negative charges in the cloud. 
A lightning flash consists of a few strokes that take place back to back within a few ten milliseconds. There may be three or four strokes or even 26 strokes in just two sec (Jewett and Serway, 2007). The interval between strokes is not detectable because of their quick succession. The strokes are triggered when there is electrical breakdown.

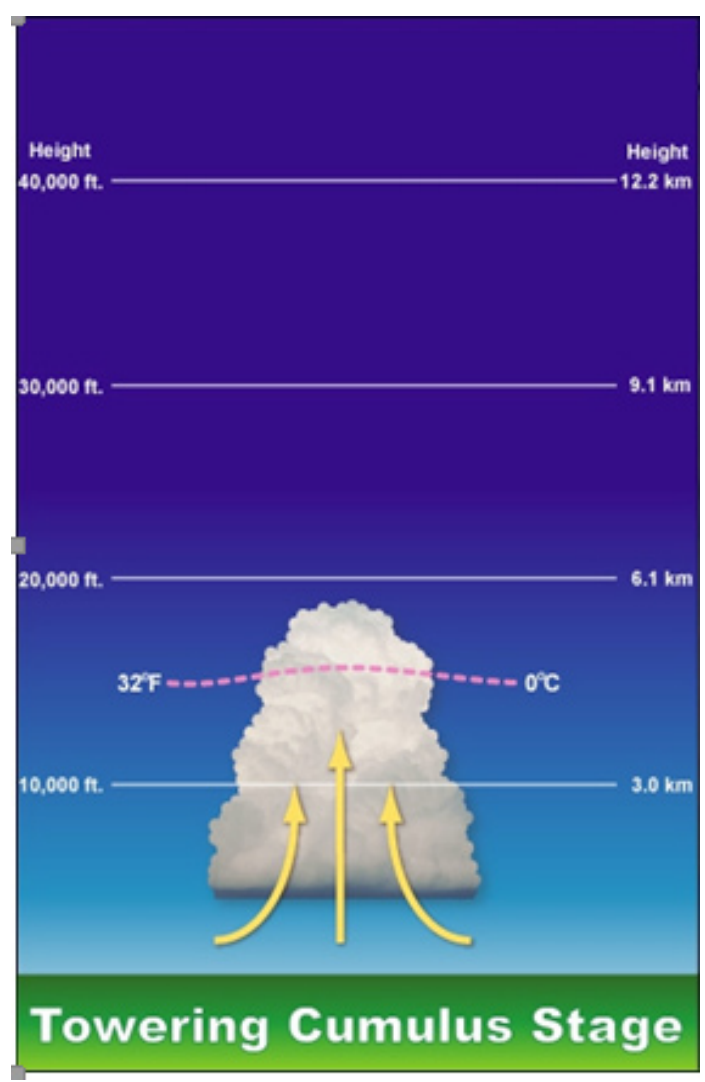

Fig1. Formation of cumulous clouds (https://en.wikipedia.org/wiki/Cumulonimbus_cloud)

At room temperature, the electrical breakdown voltage of air is 3 million volts per meter of air. The electrical breakdown creates pillar like distributions of negative charges. This is called stepped leader and approaches the ground in steps with a speed of more than a million meters per second carrying a current of 200-300 Amperes. The electrons that make up this current can make a step forward if the surrounding air has sufficient number of ions and electrons. The radius of its path is 3-4 $\mathrm{m}$. As the leader approaches the ground, it breaks down the electrical resistance of the air surrounding any sharp pointed object which loses electron because of the repulsive effect of the electrons with the leader and becomes positively charged. The breakdown of electric resistance causes a stream of positive charges upward triggering the return stroke. At a height of 20-110 meters above the ground the upward moving stream of positive charges and the downward moving negative charges neutralize creating a short circuit between the ground and clouds. Electrons rain down from the negatively charged clouds. This enormous amount of falling electrons (about 100 million trillion) carrying about 25 coulomb of electric charge creates 50,000 amperes of current.

The conductivity of the current carrying path lasts for a few thousandths of a second after the return stroke. Remaining charges made in the clouds follow the previously established path and creates another new stroke and one more bright lightning flash is observed. 
Adel $(2012$, 2013a, 2016a) shows that of all comfortable body postures in all terrains on land in the open field, prostration is the best one to get protection from lightning. This article shows what was observed in a lightning of striking a young date tree instead of much taller coconut and palm trees and many tall temples in a small congested place although the coconut and the palm trees belong to the same as the date trees. It suggests that for the protection of lives and properties against lightning in tropical/subtropical countries like Bangladesh, plenty of date trees should be grown.

Lightning starts in cumulonimbus clouds due to the separation of positive and negative charges in two parts of the same cloud due to friction in inner-cloud agitation between the tiny ice crystals in the cloud.

The first step to grow cumulonimbus clouds is the formation of cumulous clouds (Fig. 1). Hot humid air goes up, cools down due to expansion under low pressure letting moisture to condense for the formation of clouds. Heat is released in condensation. As a result, it is warmer inside the cumulous clouds than the outside. The air inside the cloud is in agitation and the cloud rises up vertically. When the cloud rise to where the temperature is the freezing point of water, large water drops and hails are formed that precipitate to the ground. The falling rain, hails, evaporation, and cooling creates the downward trend.

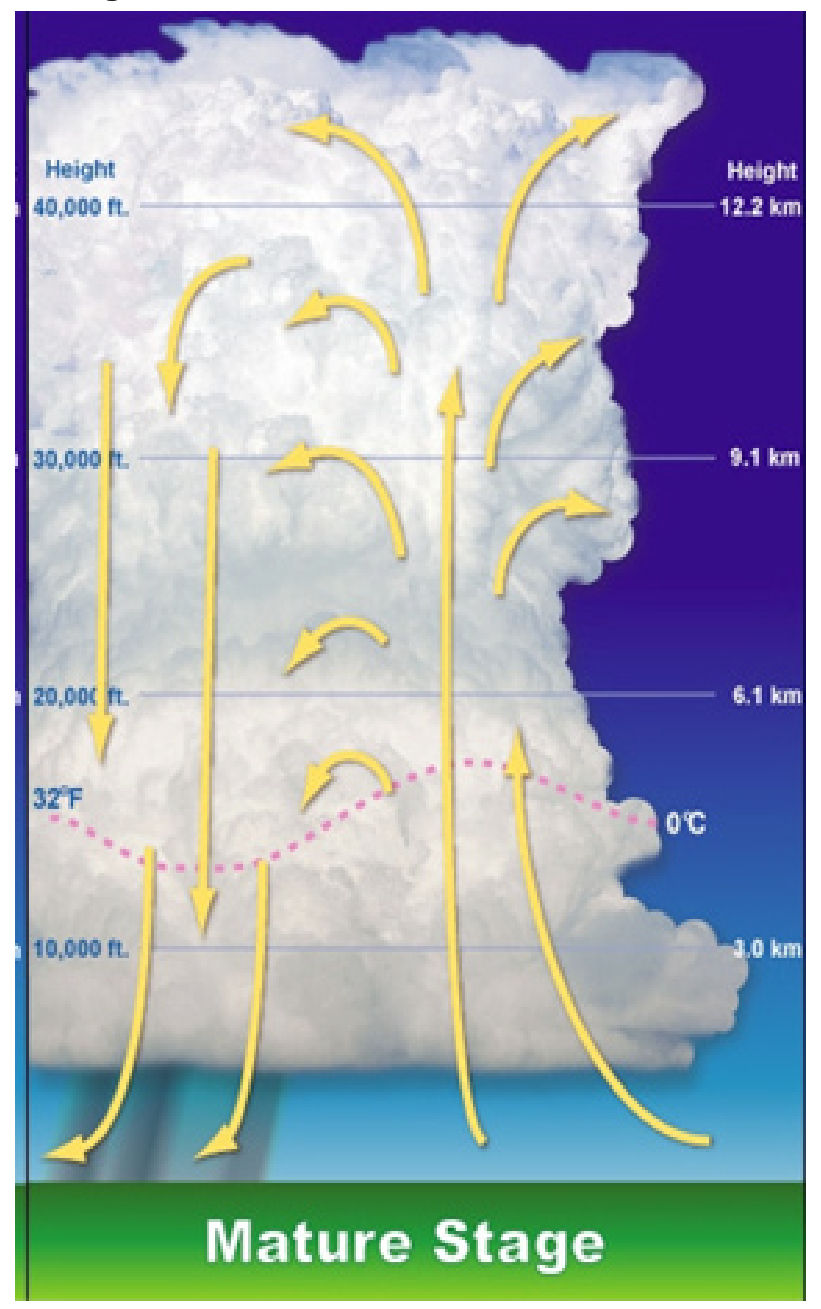

Fig2. The mature stage of cumulonimbus clouds (https://en.wikipedia.org/wiki/Cumulonimbus_cloud) 
In the mature stage, upward and downward movements work inside the cloud and starts intense lightning. The cloud rests at a height of the atmosphere at tropopause where it is calm. The top of the cloud looks like a nail head (Fig. 2). Lightning, heavy rain, hails, etc. etc. occur at this stage. Afterwards, the cloud breaks down (Fig. 3).

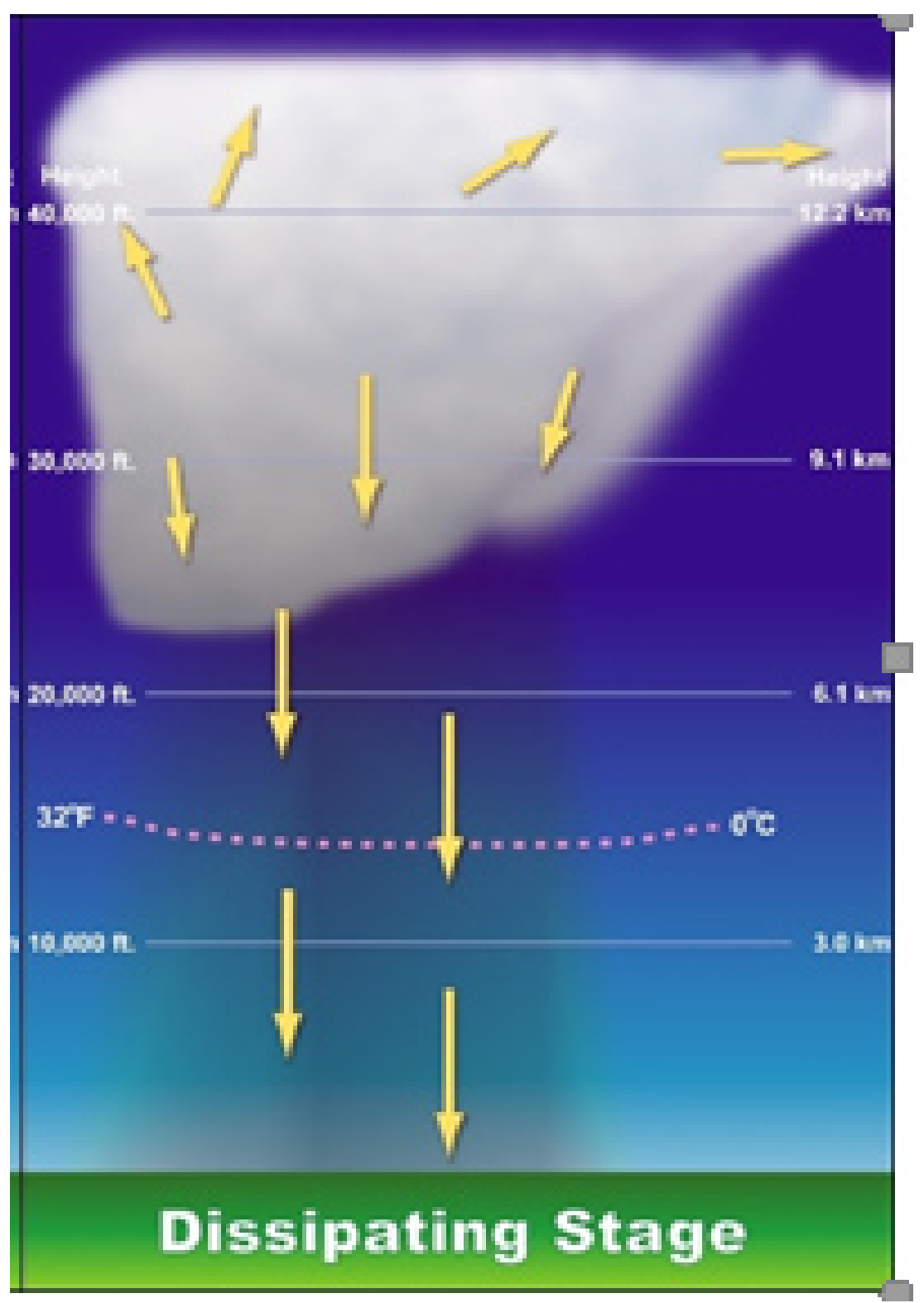

Fig3. Break-up of the cloud (https://en.wikipedia.org/wiki/Cumulonimbus_cloud)

\section{TARGET SiTE LOCATION AND LANDSCAPE}

The observation site is Puthia in the district of Rajshahi in Bangladesh. It was the place where Paresh Narayan, one of the Bhuyans of Bengal reigned. Figs. 4 through 6 describe the location of Puthia and Fig. 7. shows its landscape. There were four gates to enter the central part of Puthia that housed the palatial building, several tall temples and a market place. Each gate is located in between two dighis (huge ponds). Tall coconut trees stood on some of the dighi sides and even taller palm trees on some other dighi sides (Fig. 7). 


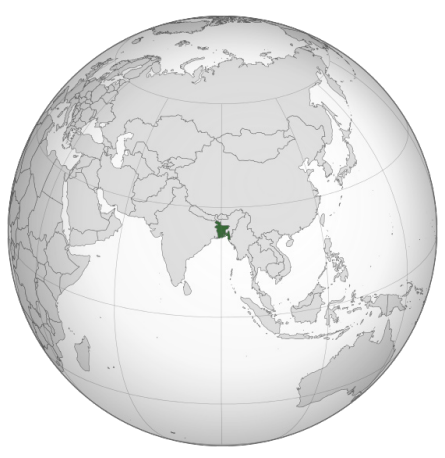

Fig4. Bangladesh on the globe

https:/commons.wikimedia.org/wiki/File:Bangladesh_(orthographic projection).svg

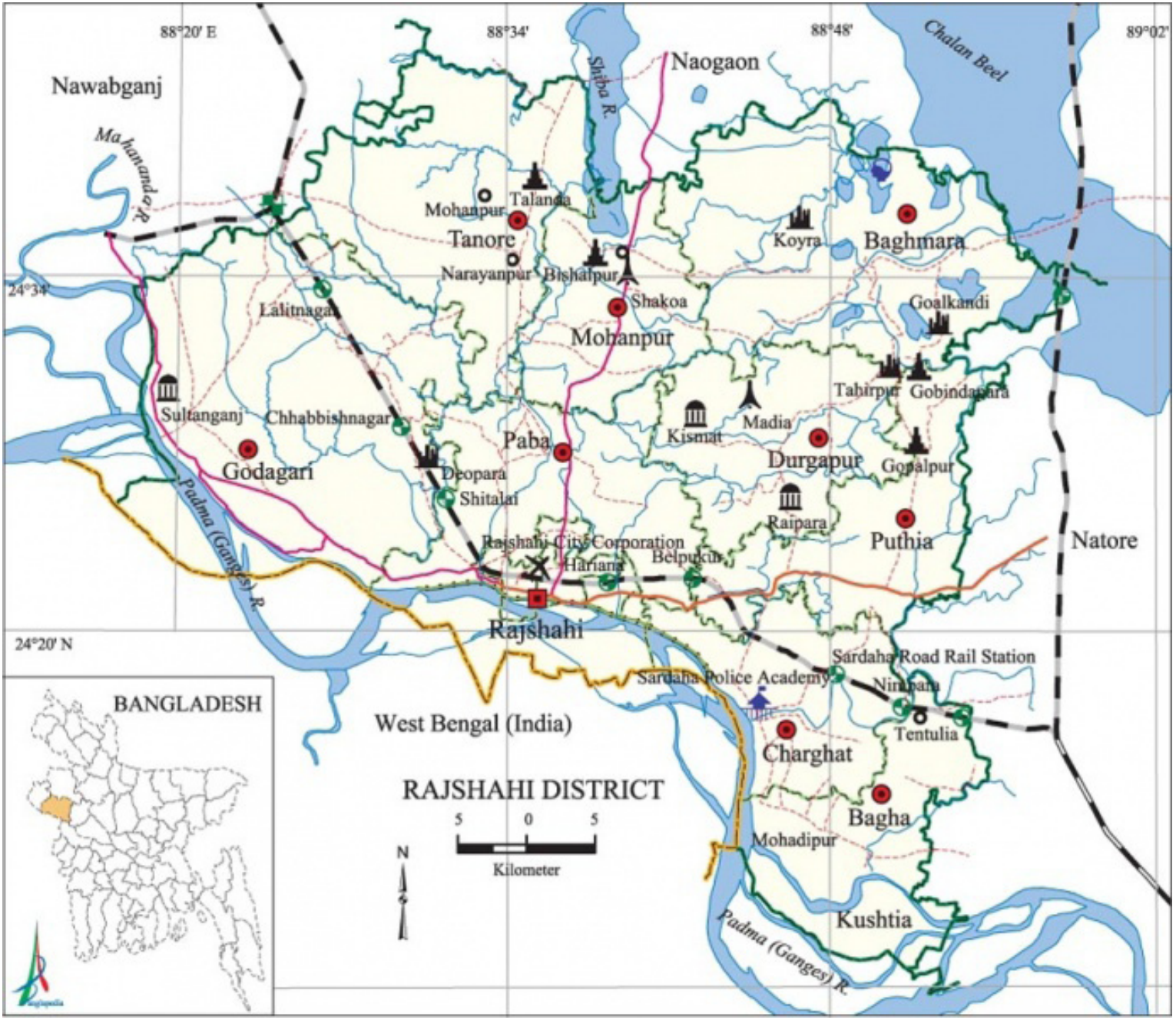

Fig5. The location of Rajshahi District and its map on the Bangladesh map. Puthia is shown near the middle of the right side boundary (Courtesy of http://en.banglapedia.org/index.php?title=File:RajshahiDistrict.jpg) 
American Research Journal of Physics (ARJPS)

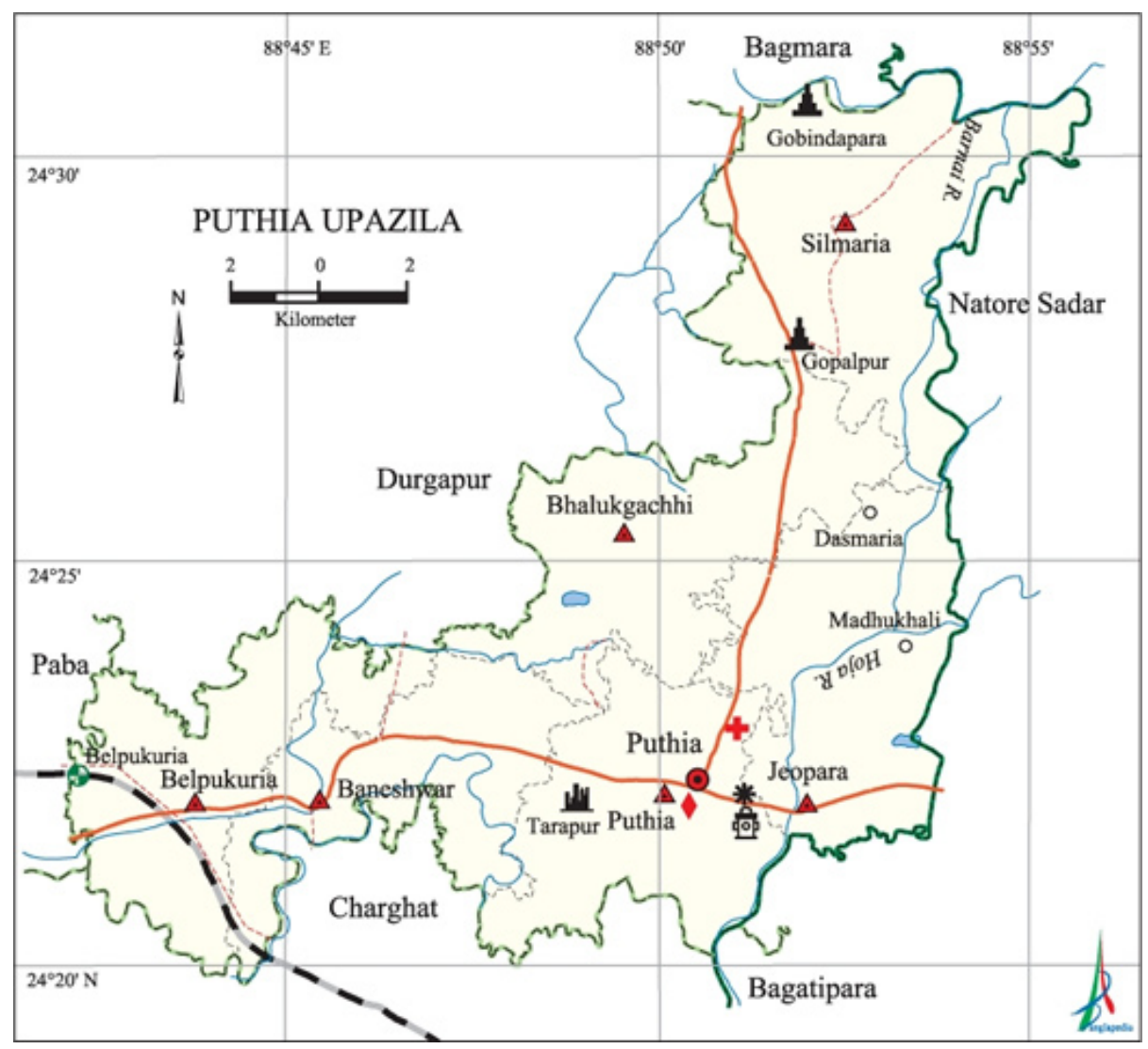

Fig6. Puthia Upozila map (Courtesy of http://en.banglapedia.org/images/6/6c/PuthiaUpazila.jpg)
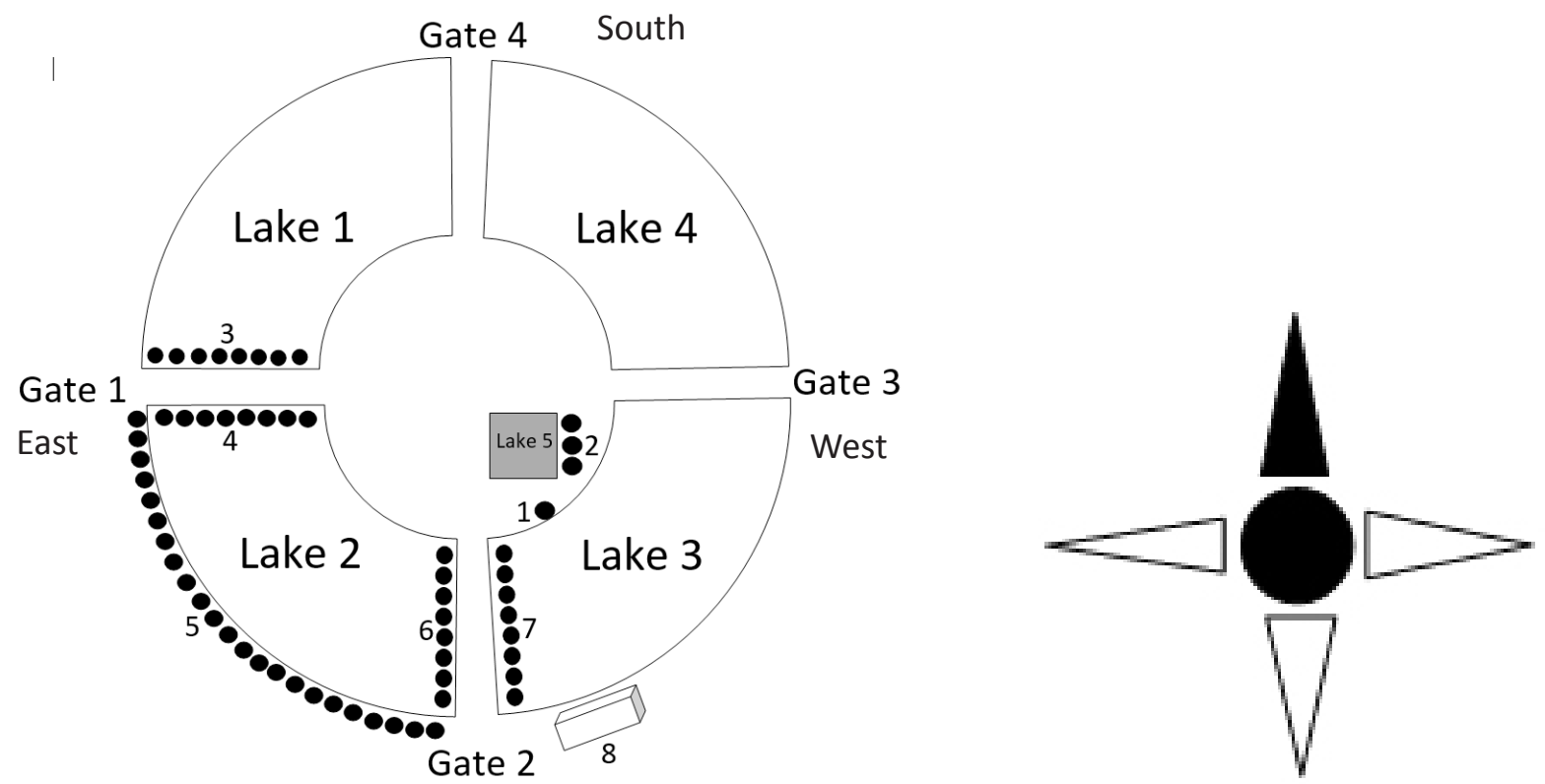

Fig7. Landscape of the Puthia central part

$\mathrm{N}$

Volume 2

Page 6 


\section{LANDSCAPE OF PUTHIA}

A rough landscape of Puthia is shown in Fig. 7 in which \#1 represents the location of a date tree of about 5-m high up to the top of its crown leaf. A date tree of about this size is shown in Fig. 8(a). \# 2 in Fig. 7 represents the location of a number of palm trees about 40-m high on the west bank of Lake 5 or Shyam Sagar as is known. A number of palm trees are shown in Figs. 8(b) and 8(c). \#s 3, 4, 5, 6, and 7 in Fig. 7 represent the rows of coconut trees of about $20-\mathrm{m}$ high. These rows would exactly look like as the date tree shown in Fig. 9 . \# 8 in Fig. 7 is the location of the high school dormitory where the author was located. Lakes 1, 2, 3, 4, and 5 were artificially excavated ones on a low land by the king. The King's Palace and all the temples are located within the area bounded by the interior boundary of the lakes. Figs. 10 show those historical structures. Gates 1, 2, 3, and 4 in Fig. 7 were made in between the water bodies to make the king's residence secure and the gates looked like the entrance gate through the rows of date trees in Fig. 9. The distance between the date tree \#1 and the high school dormitory was about $70 \mathrm{~m}$. The distance between date tree and the palm trees around lake 5 were about $100 \mathrm{~m}$. The coconut trees in rows 6 and 7 were within 50 to $70 \mathrm{~m}$.

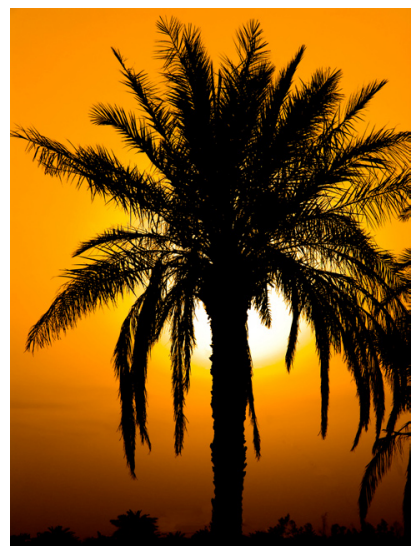

(a)

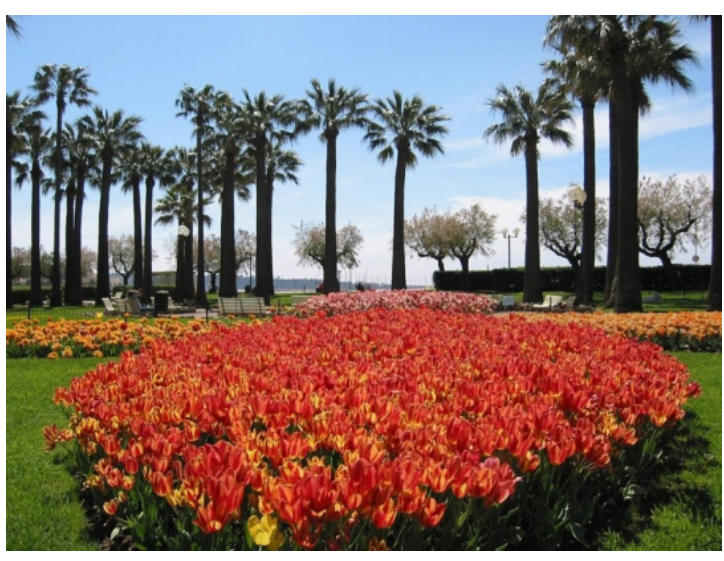

(b)

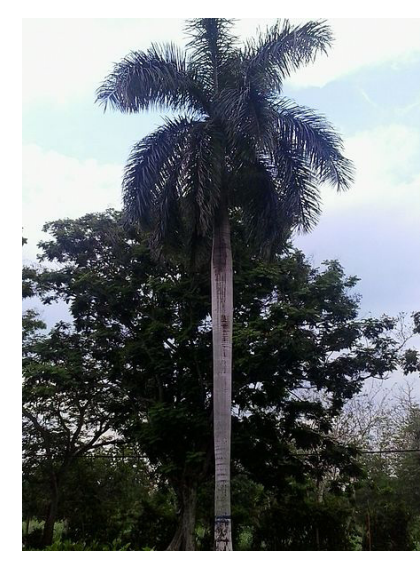

(c)

Fig8(a). A date tree (https://upload.wikimedia.org/wikipedia/commons/8/82/Nakhl-Minoo.jpg) 29 August 2012);

Fig8(b). Palm trees (Henri Kerschbaumer's 2012);

Fig. 8 (c). A Cuban Royal Palm (Bono, 2013)

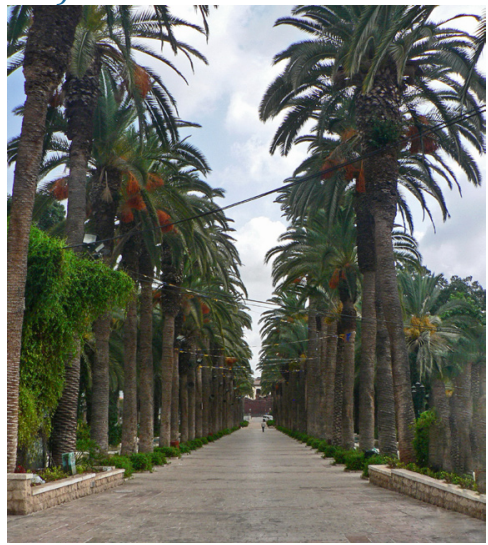

Fig9. The rows of coconut trees on gate 1 and gate 2 would look as shown here imagining there are dighis on each side of the date trees (MathKnight, 2013). 


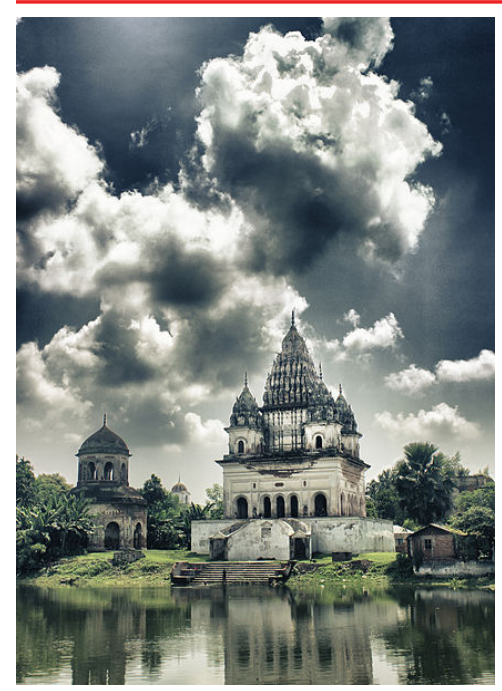

(a)

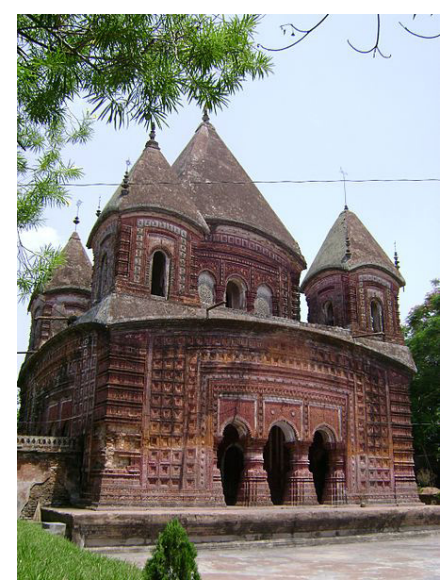

(d)

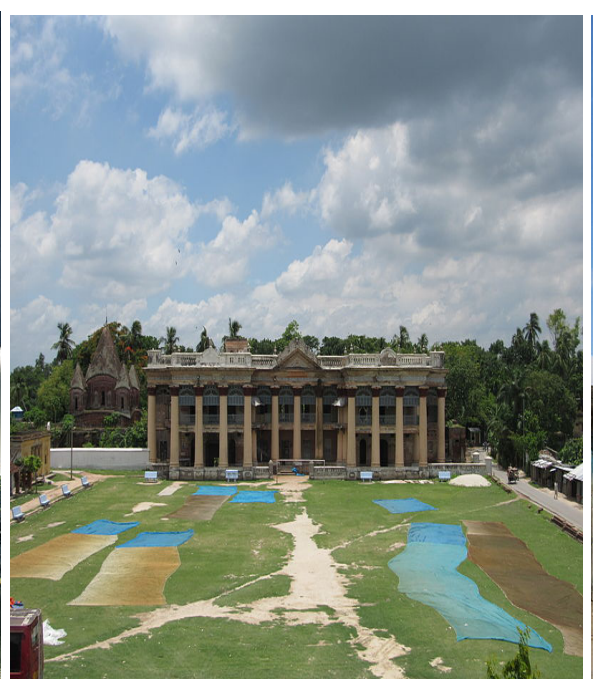

(b)

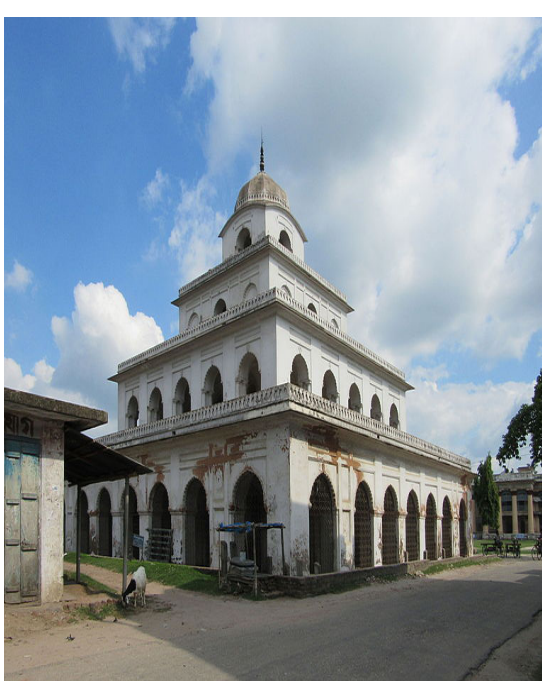

(c)

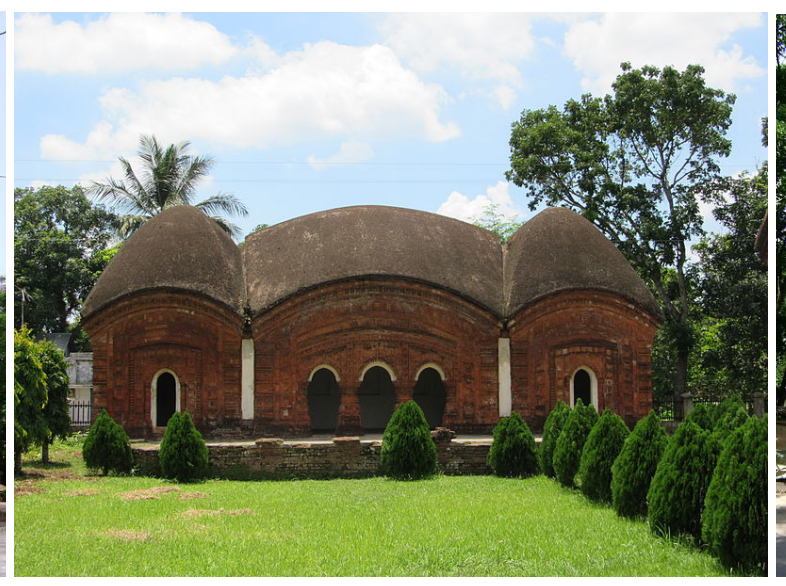

(e)

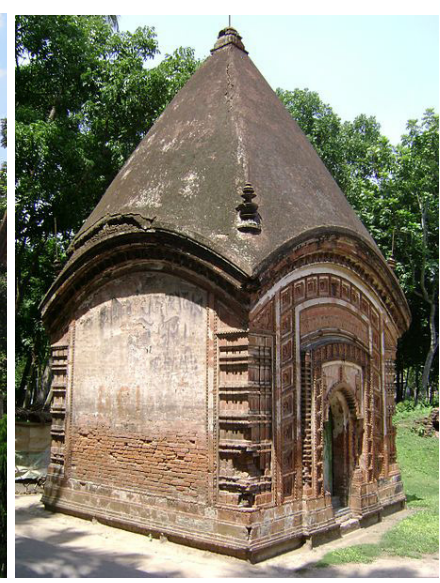

(f)

Fig10 (a). Shiva Temple at Puthia (Saikat, 2012) with the Lake \#2 on the front; Fig. 10(b). King's Palace at Puthia (Morshed, 2015a);Fig. 10(c). Puthia Mandirs (Paurag, 2008a); Fig. 10(d). Dol Mandir at Puthia (Morshed, 2015b); Fig. 10 (e ). Puthia Mandirs (Paurag, 2008b); Fig. 10 (f). Bara Ahnik Mandir at Puthia (Morshed, 2008c)

The author and two of his friends, with T-shirts on, were preparing some academic lessons sitting in an open-door room of the high school dormitory. The room was facing one of the dighis (Lake \# 3). The author and his classmates we were on the north side of the dighi that was full of water. On the south bank of the dighi there a few houses, a cooperative store, and some shoe repairers' businesses. On the north-west corner of the cooperative store building, there was the young and healthy date tree (Figs. 7 and 8(a)).

It was late morning time. People were out - some were coming to and some returning from the market located in the central place. The sky was covered with semi-dark clouds. The sun was invisible. There was no sound of lightning or thundering. Suddenly, the author and his classmates felt white patches of light touching the bare skins left-out by the sleeveless T-shirts and were creating burning feelings. On looking through the door, it was found that the date tree's top part exploded and was giving out whitish smoke from the vaporization of its sap. The patches of light known as the side flash, traveled over about 80- m (70-m water body plus some overland 
distance) to reach the author's room. The author and his friends realized that it was a lightning strike and ran to another room for shelter.

Date trees (phoenix dactylifera), coconut trees (cocos nucifera), and palm trees (roystonea) belong to the same botanical family Arecaceae which is alternatively called Palmae. Coconut trees have wider and larger leaves in longer branches than the palm trees. These trees were many in number and much larger and taller than the date tree. Palm trees were even taller than the coconut trees but shorter leaves the coconut trees. Coconut trees accumulate water in coconuts at its head. Palm trees do not. Date trees give out sweet sap if carefully scraped its bark near the heads.

There were very tall temples measuring about 60 -m high with metal caps on them. These were of concrete structure with no electrical connections or plumbing. There were houses with electricity supply in the town with tall trees in their premises. Also, there was a tin shade of about $8 \mathrm{~m}$ high with about $6 \mathrm{~m} \times 40 \mathrm{~m}$ open space underneath the shade for vendors to sell their products. The shade was supported by narrow steal pillars. There were people walking on the street on the other side of the date tree. None of them were targeted for streamers (the upward moving positively charged column).

\section{OBSERVATIONS}

1. The following observations were made:

2. Date trees are preferred ground objects

3. Lightning can hit without thundering sound

4. Side flashes can travel over long distances across a water body

5. Side flashes are white in color

6. Side flashes caused burning feeling as they discharged in our bodies

\section{Discussion AND CONCLUSION}
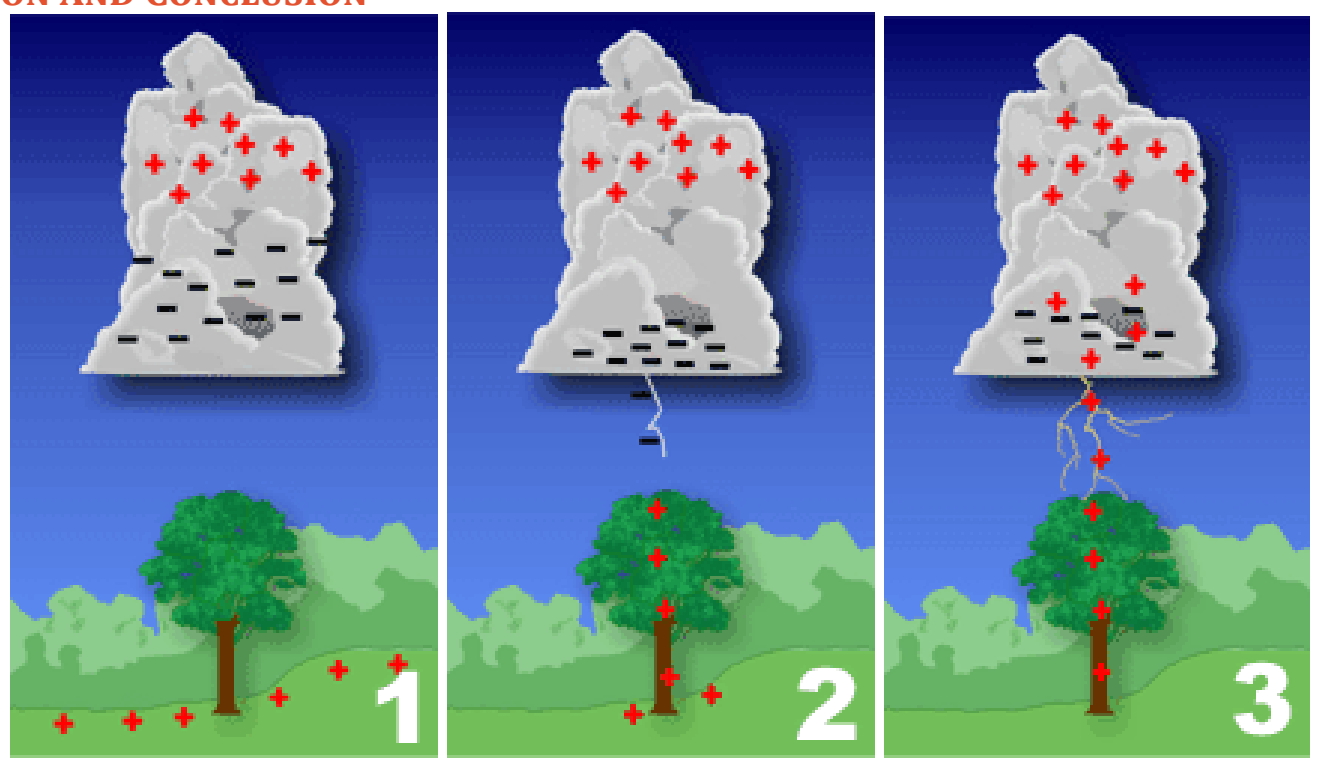

Fig11. Negatively charged cumulonimbus cloud base induces positive charges on the ground objects due to induction. (http://www.srh.noaa.gov/srh/jetstream/lightning/lightning.html)

The central part of Puthia measures about 80,000 sq m. The netively charged cloud base (Fig. 11) would be 
many times larger than this ground size since the cumulonimbus cloud base may extend several miles across and formed within 200 to 4,000 meters (https://en.wikipedia.org/wiki/Cumulonimbus_cloud) Consequently, all of Puthia would be coming under the induction of the cloud base. None of the taller living and non-living objects mentioned in Figs. 7 through 10 could develop a positive charge column except the date tree (Figs. 7 and 8(a)). This supports the fact that date trees are lightning-friendly.

As said above date trees, coconut trees, and palm trees belong to the same family. The difference among them is that the date trees are very sappy trees. Depending on the health of the tree, it can yield one to three gallons of sap in an interval of about 10 hours of winter nights (Fig. 12 (a)). The sap is mostly water. Coconut trees and palm trees may not be as sappy as date trees which makes the latter lightning catchers. Date trees yield a good quantity of sap at a very young age. Also, they flower at younger ages than coconut trees. Tropical countries like Bangladesh that is hard-hit by lightning can grow date trees abundantly to get protection from lightning strikes.

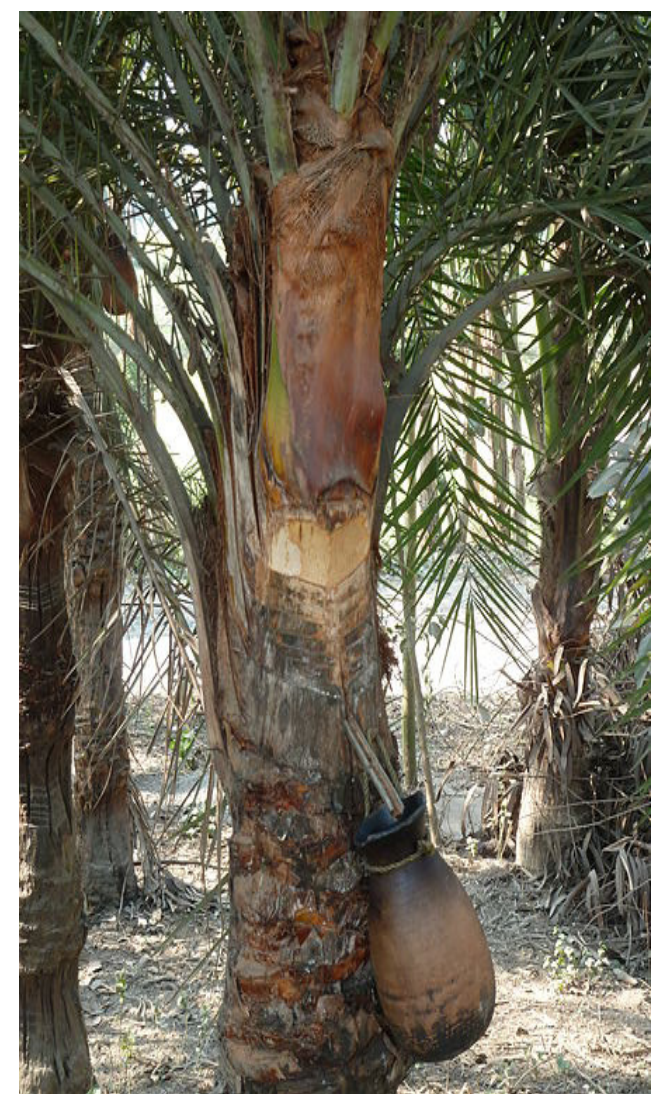

(a)

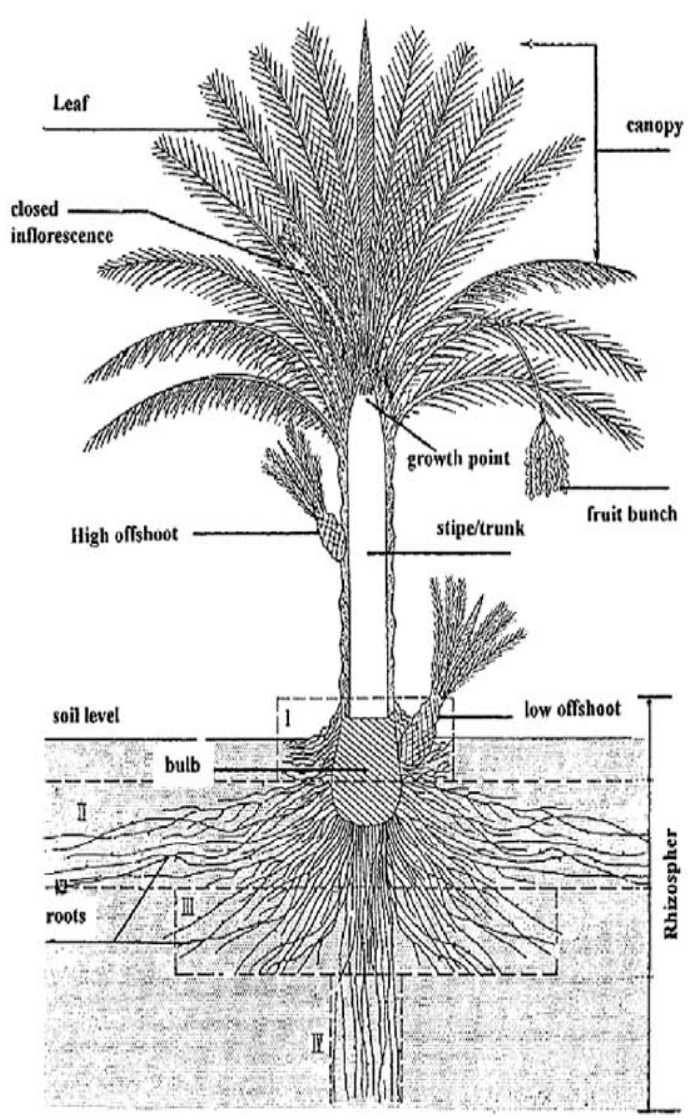

(b)

Fig12 (a). Date tree sap extraction (Balaji, 2012); Fig. 12 (b). A young dichotomously branched date palm (Phoenix dactylifera L.) at Afechtal grove (Marrakesh, Morocco). (Source: Munier, 1973 and Oihabi, 1991)

The lightning was not a bolt from the blue because the sky was overcast with clouds and the Sun was not visible. Sound shows reflection and refraction phenomena. So does the thunder. Atmospheric density variations guide the thunder sound through reflection and refraction. Atmospheric condition might had directed the thundering sound in a direction away from the target that made people missed the thundering sound. 


\section{American Research Journal of Physics (ARJPS)}

As to the side splash entering our bare skin and no such complaints from passersby, the reason could be the conductivity of moist air above the water surface. Looking at the affected trunk, the author could realize that they were almost at the same level as the affected part because their floor was about $1.5 \mathrm{~m}$ to $2 \mathrm{~m}$ above the street level and they were straight down from the target above the water body. It is inferred that it is not advisable to be around a waterbody as a protection from lightning. Over the water body, the side flash can travel for over long distances. The whitish side flash was the result of emission by the combined ionized gases.

The roots of a date tree are not like those of branchy trees (Fig. 12(b). The primary roots vary in length from 4 to 10 meters with diameters of 7 to $12.5 \mathrm{~mm}$. In a deep loamy soil, $85 \%$ of the roots are distributed within 2-m depth and 2-m on both lateral sides (Munier, 1973). Like branchy trees, date trees do not have roots in the top soil. The concentrated and deep-rooted roots suck the underground moisture and make the trees survive in water stresses and droughts. Following the root paths, the charge might have gone much below the top soil (at least as deep as the roots are) before spreading all around covering more areas underneath the lake bed than other directions because of wetness.

The South Asian country Bangladesh has been hard-hit by lightning in the wake of severe climatic changes due to the prime reason of decades-long upstream Indian water piracy (Miah, 1989; Adel, 1999, 2000, 2001, 2001) that has almost depleted the surface and groundwater in the north and the northwest (Adel, 2013b, 2015a, 2015 b, 2015c, 2015d, 2015e, 2016b). Her virgin inland seasonal and perennial shallow and deep water bodies were storing annually about 18 million trillion calories of heat (Adel et al., 2014). In the absence of the heat-storing surface water bodies, this heat supplies the due ingredient of hot and humid air for the formation of the lightning clouds the way stated above, the humidity being supplied by the flooded rice fields with groundwater (Fig. 13).

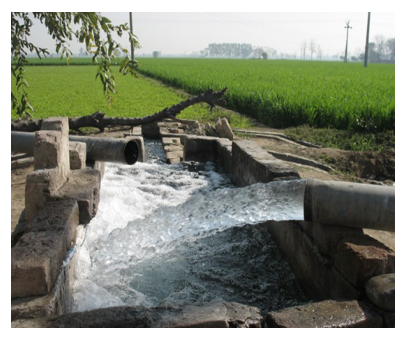

(a)

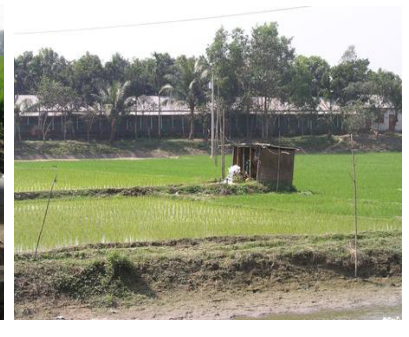

(b)
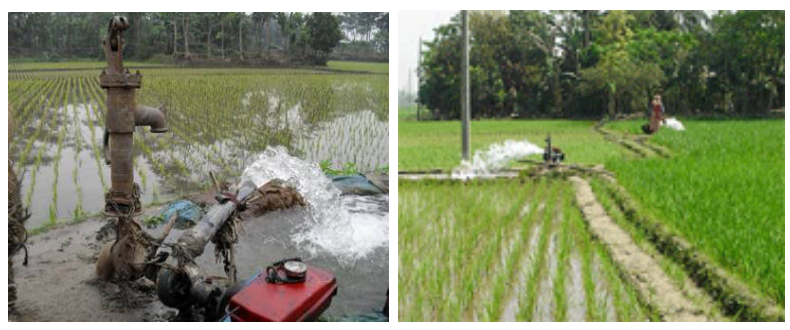

(c) (d)

Fig13. Massive groundwater withdrawal to flood rice fields. (a) https://www.ucl.ac.uk/rdr/irdr/generalnews/groundwater-arsenic-pollution-bangladesh; (b) https://www.seed.abe.kth.se/en/om/avd/lwr/grupper/ forskningsomraden/egc/forskning/assessment-of-arsenic-and-manganese-in-the-rice-of-bangladesh-throughgroundwater-and-soil-1.295577; (c) https://www.google.com/search?q=image+of+groundwater+irrigation+in +Bangladesh\&espv=2\&biw=1920\&bih=955\&tbm=isch\&imgil=qJsHkcOFJZ5GkM\%253A\%253BOZW7B4Pga41r_M \%253Bhttp\%25253A\%25252F\%25252Fwww.sos-arsenic.net\%25252Fenglish\%25252Fsource\%25252F\&source $=i u \& p f=m \& f i r=q J$ sHkcOFJZ5GkM\%253A\%252COZW7B4Pga41r_M\%252C_\&usg=_i486XeYHdXIDZ77pu1GBEqeO alk\%3D\&dpr=1\&ved=0ahUKEwi9x-ac8MrNAhVm1oMKHQPDDzsQyjcINQ\&ei=OoJyV71C5qyPBIOGv9gD\#imgrc=j dS7aHEcqv7sXM\%3A; (d) http://www.thefishsite.com/articles/641/can-ricefish-farming-provide-food-securityin-bangladesh/

Opposite to the world statistics of lightning-injured victims surpassing the fatalities, it seems the reverse is happening in Bangladesh in the Ganges delta. In Bangladesh, the probability of lightning-hit is one in 12,000 


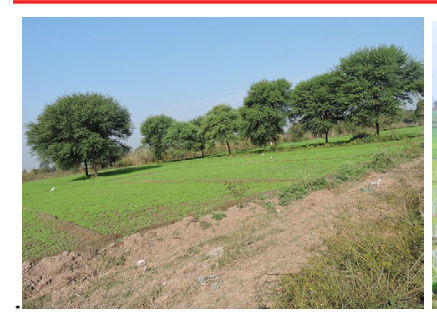

(a)

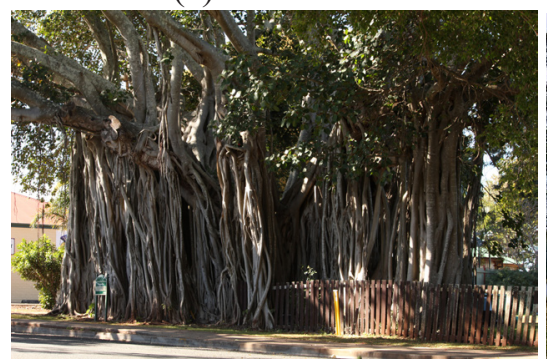

(e )

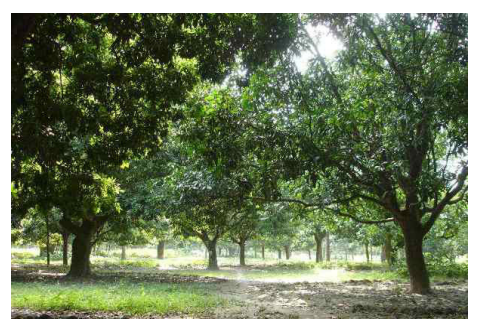

(i)

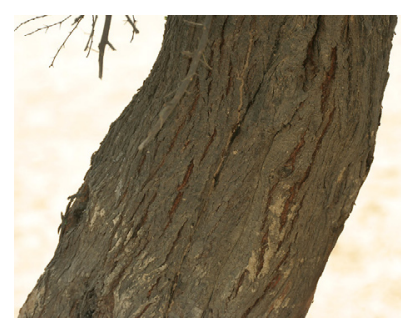

(m)

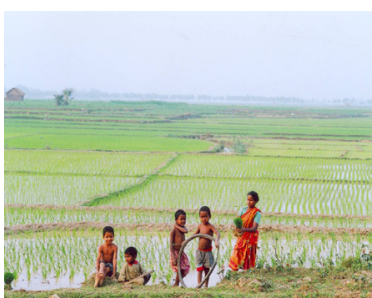

(b)

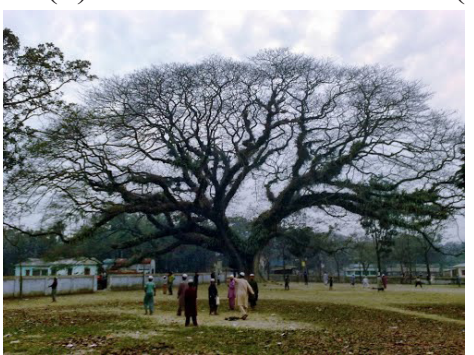

(f)

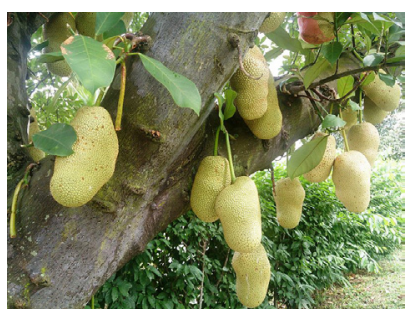

(j)

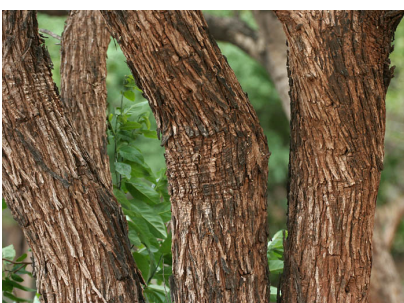

(n)

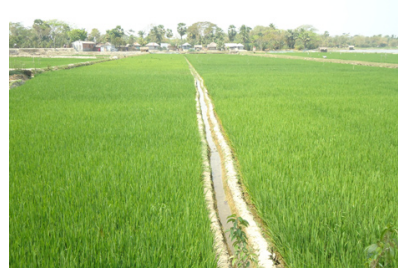

(c)

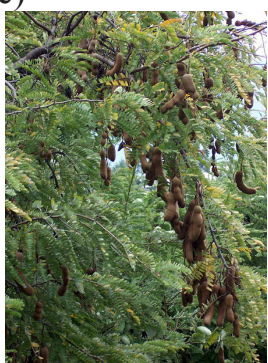

(g)

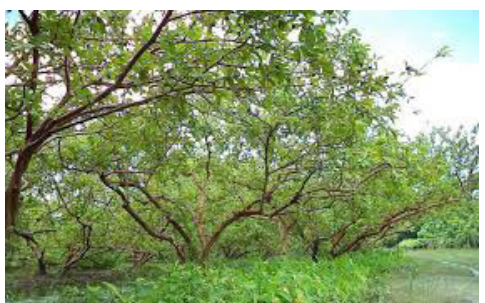

(k)

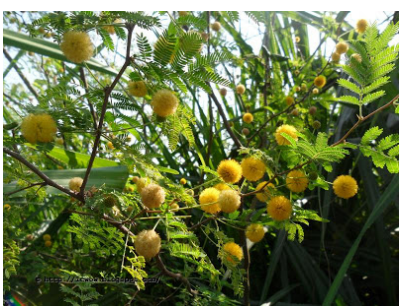

(o)

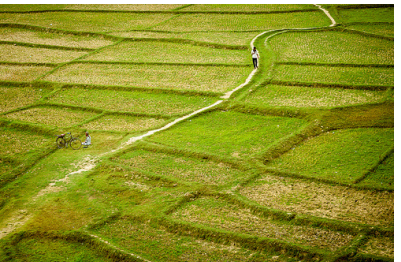

(d)

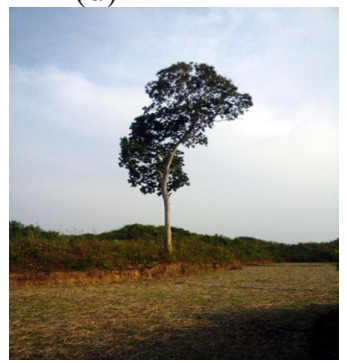

(h)

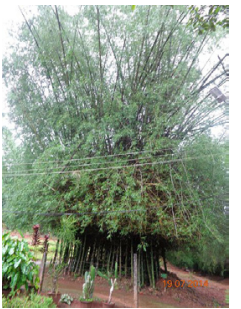

(1)

Fig14 (a). Counting from the left in each row (a) Babla tree decorated agricultural fields (Chandigarh, 2015); Fig14 (b). Treeless rice fields (Courtersy of http://londonminingnetwork.org/2013/06/uk-governmentaccepts-complaint-over-gcm-resources-bangladesh-coal-mine-british-company/)); Fig14(c). Treeless ricefields (courtesy of https://upload.wikimedia.org/wikipedia/commons/0/04/Two_paddy_fields_in_Khulna\%2C_Bangladesh. JPG) Trees appear only by the house side. Fig14(d). Courtesy of http://www.bangladeshnewsblog.com/rice-fieldscomilla-bangladesh/ (Image by R.H.Sumon ${ }^{\mathrm{TM}}$ Photo Captured from Rajshahi, Bangladesh.); Fig14(e ). A huge banyan (NJM2010, 2011). Fig14 (f). A rain tree Courtesy of https://mw2.google.com/mw-panoramio/photos/ medium/101541850.jpg); Fig14(g). A tamarind tree (B.navez, 2005); Fig14(h). A black berry tree (Aziz, 2016); Fig14(i). Mango garden (courtesy of http://www.techtunes.com.bd/reports/tune-id/65764); Fig14(j). A Huge Jackfruit tree (ProjectManhattan, 2013); Fig14(k). Guava plant (courtesy of http://www.somewhereinblog.net/blog/ 
krsiddiq/30112948); Fig14(1). A Bamboo pocket (Dvellakat, 2014). A bamboo garden size would be more than acre of land. Fig14(m). Babla tree trunk (Garg, 2007); Fig14(n). Khayer tree trunks (Garg, 2008); Fig14(0). Flowers in babla tree (http://icwow.blogspot.com/2012/01/babla-ful-acacia-nilotica.html). The picture was taken to show the flowers only. No trunk is shown. Fig14(p). Khayer tree (Courtesy of http://article.wn.com/view/2015/08/20/ Deforestation_serious_threat_to_bats_in_India_u/)

whereas in the USA it is one in 700,000. Deaths of victims are happening to people working in the field, on their way to get back goats and cattle from the field, going to pick mangoes, taking trips in open vehicles plying on land and waterways, making congregational prayers, etc. etc. In 2015, 274 people died. By May 2016, already, 189 died of lightning strikes. The fatalities in the month of May 2016 alone was 132. On 12 May 2016, 47 died (Amar Desh, 2016). In this over-populated land-scare country with fertile land, wild-grown century-old huge branchy trees like banyan trees, rain trees, tamarind trees, blackberry trees, and mango trees that were as high as 30 meters were cut down. Also, the wild-grown guava trees, jackfruit trees, cotton-producing shimul trees, the wooden plow-making babla trees and the color-producing khayer trees of height about 10 meters are rarely seen. Further, bamboo gardens are almost extinct. Furthermore, there were many other wild-grown fruit trees as well as no fruit-producing trees. The deforestation was done for a variety of reasons like clearing lands for agricultural productions (crops do not grow under tree-covered areas), fuel for brick factories, furniture wood, livelihoods, etc. The planned re-forested fruit trees are not as high as and as random as the naturally grown ones. The shortage of trees has paved the way for lightning strikes man, animals, and houses. Fig. 14 illustrates these pictures.

In the sixties and beyond, typical agricultural lands would look like the scene shown in Fig. 14 (a). But because of crops not growing under the trees, trees are not let grow in the field. If there are trees and plants, these would be around the houses. Date trees would be beneficial for the farmers because of its root characteristics that it draws moisture from deep underground and not from the top soil which may be cultivated for crop production, and, as demonstrated in this article, at the same time these can catch lightning because of tall structures and being sappy.

\section{ACKNOWLEDGEMENT}

The author is grateful to those individuals and agencies whose excellent illustrations have beautified the work. M. M. Hossain did the drawing of the rough map of Puthia and indicated the locations of the trees and water bodies and the subject location as per the instruction from the author.

\section{REFERENCES}

Al-Abdulaziz, A.U., S.M. Bashi and A.A. Atthubaiti, 2006. Analysis of the over-voltages produced by lightning strokes in the power transmission system in the Southern Region of Saudi Arabia. Am. J. Applied Sci., 3: 1755-1759. DOI: 10.3844 /ajassp. 2006.1755.1759

Adel, M. M., 1999. The impact of climatic extremes and water shortage upon human health, World Resource Review, vol. 11 no. 4, pp. 576-601

Adel, M. M., 2000. Microlevel climate change in the Ganges basin, Journal of the Arkansas Academy of Sciences, vol. 53, pp. 83-91

Adel, M. M., 2001. Effects on downstream water resources from upstream water diversion in

the Ganges basin, Journal of Environmental Quality, vol. 30. Pp.356-368.

Adel. M. M., 2002. Man-made climatic changes in the Ganges basin, International Journal of Climatology, vol. 22, pp. $993-1016$ 
Adel, M. M., 2011. Prostration the Safest and Tranquillest Refuge from Lightning (2011), newsfrombangladesh. net/view.php?hidRecord=344922

Adel, M. M., 2012. Superiority of Prostration as a Protection from Lightning Strike, Physics International 3 (1): 9-21, 2012 ISSN 1948-9803; DOI: 10.3844/pisp.2012.9.21

Adel, M. M., 2013a Seiday Abasthan Bajraghat Theke Paritran (in Bengali) meaning prostration gives the safest shelter from lightning strikes. Published by Dibbo Prakash, Dhaka, Bangladesh

Adel, M. M., 2013b. Jaladasyupana (in Bengali) meaning water piracy. Published by Dibbo Prakash, Dhaka, Bangladesh

Adel, M. M., 2015a. The Dam-Deluged Gasping Ganges Vol. 1, published by German Academic Publishing Company Lap Lambert

Adel, M. M., 2015b. The Dam-Deluged Gasping Ganges Vol. 2, published by German Academic Publishing Company Lap Lambert

Adel, M. M., 2015c. The Dam-Deluged Gasping Ganges Vol. 3, published by GermanAcademic Publishing Company Lap Lambert

Adel, M. M., 2015d. Farakka Barrage Vol 1: The Symbol of Bluffing, Blackmailing, Bullying, and Cornering Downstream for Upstream Water Piracy, published by German Academic

Publishing Company Lap Lambert Adel, M. M., 2015e Farakka Barrage Vol 2: The Symbol of Bluffing, Blackmailing, Bullying

and Cornering Downstream for Upstream Water Piracy, published by German Academic Publishing Company Lap Lambert

Adel, M. M., 2016a. Bajraghat Hraser Upay (in Bengali) meaning the means of reducing lightning hit, Thikana, July 8, New York

Adel, M. M., 2016b. Treeteo Jobjagat (in Bengali) meaning Bio-World III. The author presents a case study of the integrated effects of drying rivers at the downstream by the upstream water piracy in the Ganges basin. Publisher Dibbo Prakash, Dhaka, Bangladesh (in press)

Adel, M. M, M. R. Hossain, and S. F. Hossain, 2014. Climatic Severity Victims of Upstream Water Piracy strongly Evidencing Inland Water Depletion-Caused Global Warming Vis-à-vis Cooling, American Journal of Environmental Science 10 (2): 171-198, 2014 ISSN: 1553-345X (C2014 Science Publication doi:10.3844/ ajessp.2014.171.198 Published Online 10 (2) 2014 (http://www.thescipub.com/ajes.toc)

AzizA,(http://www.banglatribune.com/country/news/94893/\%E0\%A6\%B2\%E0\%A6\%BE\%E0

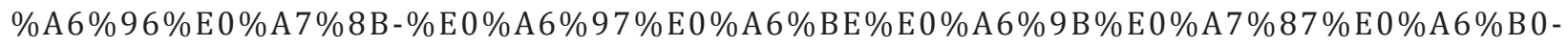
\%Е0\%A6\%AC\%Е0\%A6\%A8\%Е0\%A7\%87-\%Е0\%A6\%86\%Е0\%A6\%9B\%Е0\%A7\%87-\%Е0\%A6\%95\%Е0\% A7\%87\%Е0\%A6\%AC\%E0\%A6\%B2-\%E0\%A6\%8F\%E0\%A6\%95\%E0\%A6\%9F\%E0\%A6\%BF-\%E0\%A6\%9C \%Е0\%A6\%BE\%Е0\%A6\%AE\%Е0\%A6\%97\%Е0\%A6\%ВE\%Е0\%А6\%9B

B. navez, File:Tamarindus_indica_pods.JPG, 12 September 2005. Available from https://commons.wikimedia. org/wiki/ File:Tamarindus_indica_pods.JPG

Balaji, File:Sweet_sap_from_date_palm.JPG. 4 February 2012. Available from https://commons.wikimedia.org/ wiki/ File:Sweet_sap_from_date_palm.JPG 
American Research Journal of Physics (ARJPS)

Bono, File:Palma_Real.jpeg. 24 November 2013. Available from https://en.wikipedia.org/wiki/ File:Palma_ Real.jpeg

Chandigarh H, File:Vachellia_nilotica,_Village_Behlolpur,_Punjab,_India.JPG, 13 November 2015. Available from https://commons.wikimedia.org/wiki/File:Vachellia_nilotica,_Village_Behlolpur,_Punjab,_India.JPG

Dell'Amore, C., 2010. A new lightning type found over volcano? National Geographic Society.

Demirkol, M.K., U.S. Inan, T.F. Bell, S.G. Kanekal and and D.C. Wilkinson, 1999. Ionospheric effects of relativistic electron enhancement events. Geophys. Res. Lett., 26: 3557-3560. DOI: 10.1029/1999GL010686

Desk Report, Amar Desh, Najeerbiheen bajrapat ebar Bharate, ekdeene nihoto 79, 22 June 2016. Available from http://www.amardeshonline.com/pages/details/2016/06/22/341305\#.V2qCMrgrKUk

Djalel, D., H. Ali and C. Faycal, 2007. The return stroke of lightning current, source of electromagnetic fields (study, analysis and modeling). Am. J. Applied Sci., 4: 42-48. DOI: 10.3844/ajassp. 2007.42.48

Dvellakat, File:Bambusa_bamus.JPG, 19 July 2014. Available from https://commons.wikimedia.org/wiki/ File:Bambusa_bamus.JPG

NJM2010, File:Banyan_tree_Cleveland.jpg, 23July 2011. Available from https://commons.wikimedia.org/wiki/ File:Banyan_tree_Cleveland.jpg

ProjectManhattan, File:Jackfruit_tree_Singapore.jpg, 3 December 2013. Available from https://commons. wikimedia.org/wiki/ File:Jackfruit_tree_Singapore.jpg

Garg JM, File:Babool_(Acacia_nilotica)_trunk_at_Hodal_W_IMG_1252.jpg, 11 April,2007.Available from https:// commons.wikimedia.org/wiki/ File:Babool_(Acacia_nilotica)_trunk_at_Hodal_W_IMG_1252.jpg

Garg JM, File:Khair_(Acacia_catechu)_trunk_at_Hyderabad,_AP_W_IMG_7264.jpg, 15 June 2008, 15 June 2008. Available from https://commons.wikimedia.org/wiki/ File:Khair_(Acacia_catechu)_trunk_at_ Hyderabad,_AP_W_IMG_7264.jpg

Halasa, G., I. Badran and H. El-Zayyat, 2007. Lightning over-voltages on Amman-Aqaba 400KV line. Am. J. Applied Sci., 4: 1075-1078. DOI 10.3844/ajassp. 2007.1075.1078

Jewett, J.W. and R.A. Serway, 2007. Physics for Scientists and Engineers with Modern Physics. 7th Edn., Cengage Learning EMEA, Belmont, CA., ISBN-10: 0495112402, pp: 1392.

Kerschbaumer's H, ，File:Jardins_de_la_croisette,_Cannes.jpg, September 2012 . Available from https:// en.wikipedia.org/wiki/ File:Jardins_de_la_croisette,_Cannes.jpg

Khan, N., N. Mariun, I. Aris and J. Yeak, 2002. Lasertriggered lightning discharge. New J. Phys., 4: 61- 61. DOI: 10.1088/1367-2630/4/1/361.

Koopman, D.W. and T.D. Wilkerson, 1971. Channeling of an ionizing electrical streamer by a laser beam. J. Applied Phys., 42: 1883-1886. DOI: 10.1063/1.1660462

MathKnight, File:Rishon-LeZion-Gan-Moshava-0002.jpg. 23 December 2013. Available from https://commons. wikimedia.org/wiki/ File:Rishon-LeZion-Gan-Moshava-0002.jpg

Meredith, S.L., S.K. Earles and N. Turner, 2010a. The horizontal electric field induced by a lightning return stroke. J. Math. Stat., 6: 210-216. DOI: 10.3844/jmssp. 2010.210.216

Meredith, S.L., S.K. Earles and N. Turner, 2010b. The magnetic field induced by a lightning Strike's indirect effect double exponential current waveform. J. Math. Stat., 6: 221-225. DOI: 10.3844/jmssp. 2010.221.225 Phy. 


\section{American Research Journal of Physics (ARJPS)}

Intl. 3 (1): 9-21, 201222 NLSI, 2012. NLSI international lightning safety initiative. National Lightning Safety Institute.

Morshed T. File:Palace_at_Puthia,_Rajshahi.JPG, 20 June 2015a. Available from .https://commons.wikimedia. org/wiki/ File:Palace_at_Puthia,_Rajshahi.JPG

Morshed T, File:Dol_Mandir_at_Puthia.JPG, 20 June 2015b. Available from https://commons.wikimedia.org/ wiki/ File:Dol_Mandir_at_Puthia.JPG

Morshed T, File:Dol_Mandir_at_Puthia.JPG, 20 June 2015c Available from https://commons.wikimedia.org/ wiki/ File:Bara_Ahnik_Mandir_at_Puthia.JPG

Munier, P. 1973. Le palmier dattier. Techniques agricoles et productions tropicales. Maisonoeuvre et Larose edition, Paris. 221 pp

Oihabi A (1991) effects of vesicular arbuscular mycorrhizae on bayoud disease and date palm nutrition, Ph. D Thesis, University of Marrakech

Odeh, H.B., 2009. Usage of lightning arrester line to feed light electrical loads. Am. J. Applied Sci., 6: 13-23. DOI: 10.3844/ajassp. 2009.13.23

Paurag, File:Puthia_Mandirs10.JPG, 12 June 2008a. Available from https://commons.wikimedia.org/ wiki/ File:Puthia_Mandirs10.JPG

Paurag, File:Puthia_Mandirs12.JPG, 12 June 2008b. Available from https://commons.wikimedia.org/wiki/ File:Puthia_Mandirs12.JPG

Petersen, D., M. Bailey, W.H. Beasley and J. Hallett, 2008. A brief review of the problem of lightning initiation and a hypothesis of initial lightning leader formation. J. Geophys. Res., 113: 1-14. DOI: 10.1029/2007JD009036

Rambo, P., J. Biegert, V. Kubecek, J. Schwarz and A. Bernstein et al., 1999. Laboratory tests of laserinduced lightning discharge. J. Optical Technol., 66: 194-198. DOI: 10.1364/JOT.66.000194

Saikat NK, File:Shiva_Temple,_Puthia,_Rajshahi_NK_(2).jpg, 22 September 2012. Available from https:// commons.wikimedia.org/wiki/ File:Shiva_Temple,_Puthia,_Rajshahi_NK_(2).jpg

Saum, K.A. and D.W. Koopman, 1972. Discharges guided by laser-induced rarefaction channels. Phys. Fluids, 15 : 2077-2079. DOI: 10.1063/1.1693833

Stolzenburg, M. and T.C. Marshall, 2008. Charge structure and dynamics in thunderstorms. Space Sci. Rev., 137: 355-372. DOI: 10.1007/s11214- 008-9338-z

Citation: Miah M Adel, Inference and Implication from a Lightning Observation, American Research Journal of Physics, Volume 2, 2016; pp:1-16

Copyright (C) 2016 Miah M Adel, This is an open access article distributed under the Creative Commons Attribution License, which permits unrestricted use, distribution, and reproduction in any medium, provided the original work is properly cited. 